\title{
PENGEMBANGAN INSTRUMEN TES KEMAMPUAN \\ BERARGUMENTASI PADA MATERI IMPULS DAN MOMENTUM
}

\author{
Febi Dwi Putri \\ Pendidikan Fisika, FMIPA, Universitas Negeri Malang, email: \\ dewi.putri.1703216@students.um.ac.id
}

\begin{abstract}
The ability to argue is an ability that needs to be mastered by students to pass on their knowledge to others. This study aims to develop a test instrument for the ability to argue on impulse and momentum material. The test instrument was adapted from the Toulmin's Argument Pattern (TAP) model. This research includes research and development by taking a 3-D model that is define, design, and develop. A total of five items of description are made based on indicators of argumentation ability. In the results of expert validation it is obtained that the test instrument is feasible to be developed by considering the improvement of the items by expert advice. The results of the development of the whole item is valid, and has a high reliable value of 0.78 .
\end{abstract}

Keywords: development of instruments, the ability to argue, impulses and momentum.

\begin{abstract}
ABSTRAK
Kemampuan berargumentasi merupakan kemampuan yang perlu dikuasai mahasiswa untuk meneruskan pengetahuannya ke orang lain. Penelitian ini bertujuan untuk mengembangkan instrumen tes kemampuan berargumentasi pada materi impuls dan momentum. Instrumen tes diadaptasi dari model Toulmin's Argument Pattern (TAP). Penelitian ini termasuk penelitian dan pengembangan dengan mengambil model 3-D yaitu define, design, dan develop. Sejumlah lima butir soal uraian dibuat berdasarkan indikator kemampuan berargumentasi. Pada hasil validasi ahli diperoleh bahwa instrumen tes layak untuk dikembangkan dengan mempertimbangkan perbaikan butir soal oleh saran ahli. Hasil dari pengembangan keseluruhan butir bersifat valid, dan mempunyai tangkat reliabel tinggi sebesar 0.78 .
\end{abstract}

Kata Kunci: pengembangan instrumen, kemampuan berargumentasi, impuls dan momentum. 
Febi Dwi Putri : Pengembangan Instrumen Tes Kemampuan Berargumentasi pada Materi Impuls dan Momentum

\section{PENDAHULUAN}

Proses pembelajaran menuntut peserta didik untuk bertindak aktif (Handayani, 2015). Peserta didik dibelajarkan untuk mengembangkan kemampuan berpikir, kreatif, dan sikap terbuka (Sudarmo dkk., 2018). Materi fisika disampaikan secara baik dengan berorientasi aplikatif (Rahmawati dkk., 2015). Salah satu aspek yang dapat dinilai dari peserta didik yaitu kemampuan berargumentasi. Argumentasi yang dikemukakan berdasarkan fakta dan alasan yang kompleks (Herring, 2012). Penjelasan dalam berargumentasi selanjutnya diverifikasi, dikomunikasikan, diperdebatkan, dan dimodifikasi (Probosari dkk., 2015).

Kemampuan berargumentasi merupakan kemampuan yang melibatkan proses kognitif yang memungkinkan peserta didik dalam menyelesaikan masalah (Rosita, 2014). Argumentasi merupakan cara untuk mengembangkan keterampilan berpikir secara umum karena kemampuan ini mencakup kegiatan mengajukan dan mengkritik sebuah permasalahan (Cáceres dkk., 2018). Pendidik yang kompeten dapat mengembangkan dan mendorong peserta didik untuk berargumen dengan baik (Jennings \& Greenberg, 2009). Melalui kegiatan berargumentasi, peserta didik dapat memahami proses perolehan konsep pengetahuan yang sedang dipelajari (Dwiretno \& Setyarsih, 2018). Bukan hanya peserta didik yang harus mempunyai kemampuan berargumentasi, tetapi mahasiswa juga perlu untuk menguasai kemampuan berargumentasi. Argumentasi melibatkan penalaran ilmiah untuk menarik kesimpulan dari informasi yang tersedia dan pernyataan yang disampaikan berdasarkan fakta yang ada (Pallant \& Lee, 2015). Mahasiswa dituntut tidak hanya mampu menyampaikan kembali apa yang telah diperolehnya, tetapi juga harus memiliki kemampuan untuk menyalurkan pengetahuannya (Suhandi, 2012). Pendidik biasanya belum puas berkenaan dengan tingkat kualitas berargumentasi mahasiswa (Kontos, Miller dkk., 2017; Noroozi dkk., 2018). Pandangan instrumental tentang argumentasi diperlukan untuk mengembangkan soal guna penilaian kemampuan berargumentasi (Paglieri \& Castelfranchi, 2010).

Ada beberapa model untuk mengembangkan soal guna penilaian kemampuan berargumentasi salah satunya yaitu model Toulmin's Argument Pattern. Developments in the Application of Toulmin's Argument Pattern for Studying Science Discourse menyatakan bahwa aplikasi Model Argumentasi Toulmin dapat sebagai acuan dalam menganalisis argumentasi (Shirley Simon, 
2008). Dasar pengembangan instrumen tes model Toulmin's Argument Pattern (TAP) terdiri dari claim (klaim), data (data), warrant (bukti), backing (dukungan), qualifier (modalitas), dan rebuttal (bantahan) (Abduh dkk., 2019; Viyanti dkk, 2016). Mahasiswa dapat berargumen berdasarkan klaim, data, bukti, dan dukungan (Ginanjar, dkk., 2015). Berdasarkan hasil temuan (Kaniawati \& Suhandi, 2014; Suhandi, 2012) bahwa beberapa dari mahasiswa belum kompeten dalam menuliskan argumentasi sains yang dilihat dari penyertaan bukti dan dukungan yang dapat menjamin kebenaran dari klaim yang dipilih.

Pengembangan instrumen tes kemampuan berargumentasi dalam bidang fisika dapat diterapkan pada materi impuls dan momentum. Menurut hasil penelitian (Karim dkk., 2015; Rhahim, dkk., 2015) bahwa jenis kesalahan yang dilakukan mahasiswa dalam mneyelesaikan soal-soal pada materi impuls dan momentum adalah kesalahan strategi mengerjakan, kekeliruan berpikir terkait keberlakuan hukum kekekalan momentum, dan kesalahan konsep. Menurut (Rosa, Cari, \& Aminah, 2017) dalam penelitiannya menunjukan mahasiswa mengalami miskonsepsi terhadap transfer energi yang saling bertumbukan sebesar 77.27\%. Berdasarkan hal tersebut, penelitian ini dilakukan dengan tujuan yaitu mengembangkan instrumen tes model Toulmin's Argument Pattern (TAP) berupa soal uraian yang digunakan untuk mengukur kemampuan berargumentasi mahasiswa Pendidikan Fisika di Universitas Negeri Malang.

\section{METODE PENELITIAN}

Penelitian ini merupakan penelitian dan pengembangan (Research and Development) dengan mengadaptasi model 4-D dari Thiagarajan, Semmel, dan Semmel (1974) dan memodifikasi model tersebut menjadi 3-D (define, design, dan develop). Penelitian dan pengembangan ini dilaksanakan selama empat bulan (Agustus - November 2019) di Jurusan Fisika Universitas Negeri Malang. Data yang dihasilkan dari penelitian ini adalah data kualitatif dan data kuantitatif yang diperoleh berdasarkan hasil uji coba instrumen penelitian. Instrumen penelitian yang digunakan merupakan intrumen tes kemampuan berargumentasi pada responden yang dipilih secara acak. Responden terdiri dari 25 mahasiswa semester lima Pendidikan Fisika Universitas Negeri Malang.

Teknik analisis data dilakukan dengan menganalisis data kuantitatif dan kualitatif. Analisis kualitatif berupa saran dari ahli untuk memperbaiki instrumen tes kemampuan berargumentasi. Data kuantitatif berupa skor penilaian instrumen 
Febi Dwi Putri : Pengembangan Instrumen Tes Kemampuan Berargumentasi pada Materi Impuls dan Momentum

tes yang didapatkan dari validasi ahli dan validasi empirik yang meliputi validitas dan reliabilitas.

Data kuantitatif dari penilaian instrumen tes oleh validasi ahli disajikan pada persamaan (1) yaitu

$$
\bar{X}=\frac{\Sigma X}{N}
$$

keterangan:

$\bar{X} \quad=$ skor rata-rata

$\Sigma X \quad=$ jumlah skor

$N \quad=$ jumlah validator

Berdasarkan persamaan (1), katagori kualitatif dapat disajikan dengan kriteria penilaian ideal sesuai pada Tabel 1 .

Tabel 1. Kriteria Penilaian Validasi Ahli

\begin{tabular}{|c|l|c|}
\hline No & \multicolumn{1}{|c|}{ Rentang Skor } & Kriteria \\
\hline $\mathbf{1}$ & $\bar{X}>\left(X_{i}+1,8 S B i\right)$ & Sangat Baik \\
\hline $\mathbf{2}$ & $\left(X_{i}+0,6 S B i\right)<\bar{X} \leq\left(X_{i}+1,8 S B i\right)$ & Baik \\
\hline $\mathbf{3}$ & $\left(X_{i}-0,6 S B i\right)<\bar{X} \leq\left(X_{i}+0,6 S B i\right)$ & Cukup \\
\hline $\mathbf{4}$ & $\left(X_{i}-1,8 S B i\right)<\bar{X} \leq\left(X_{i}-0,6 S B i\right)$ & Kurang \\
\hline $\mathbf{5}$ & $\bar{X} \leq\left(X_{i}-1,8 S B i\right)$ & Sangat Kurang \\
\hline
\end{tabular}

(Sumber: Kurniawan \& Taqwa, 2018).

$X_{i}=\frac{1}{2} \times M$

$S B_{i}=\left(\frac{1}{2} \times \frac{1}{3}\right) \times M$

dengan:

$M=($ jumlah aspek x skor maksimal) + (jumlah aspek x skor minimal)

Analisis data kuantitatif juga dilakukan untuk mengetahui validasi empirik yaitu validitas dan reliabilitas instrumen tes kemampuan berargumentasi. Tingkat validitas diperoleh dari uji validitas berdasarkan uji korelasi product moment pearson, sedangkan tingkat reliabilitas diperoleh dari hasil uji cronbach alpha (Yusup, 2018). 


\section{HASIL PENELITIAN DAN PEMBAHASAN}

Hasil dari penelitian ini berupa validasi ahli dan validasi empirik. Uji validasi ahli dilakukan oleh pakar/ahli dan uji validasi empirik diperoleh dari tingkat validitas dan tingkat relibilitas. Berikut rincian hasil dan pembahasan.

\section{Tahap Define}

Pada tahap ini dilakukan analisis yang sesuai dengan kebutuhan pengembangan. Analisis yang dilakukan yaitu terhadap penilaian kemampuan berargumentasi. Penilaian kemampuan berargumentasi dapat dilakukan dengan mengembangkan beberapa butir soal uraian. Materi fisika yang diujikan yaitu mengenai impuls dan momentum. Soal uraian yang dikembangkan dapat diuji cobakan kepada responden. Responden merupakan mahasiswa yang telah menempuh materi impuls dan momentum. Setiap butir soal yang dibuat mengandung empat dari enam aspek instrumen tes model Toulmin's Argument Pattern (TAP).

\section{Tahap Design}

Pada tahap ini direncanakan pengembangan instrumen tes dengan menentukan indikator kemampuan berargumentasi. Jumlah soal pada instrumen tes sebanyak lima butir soal. Indikator yang dipilih digunakan untuk mengukur kemampuan berargumentasi yaitu diadaptasi dari aspek instrumen tes model Toulmin's Argument Pattern (TAP) (Handayani, 2015). Aspek instrumen tes model TAP yang digunakan yaitu klaim, data, bukti, dan dukungan yang berada pada penyelesaian tiap butir soal (Abduh, Sastromiharjo, \& Anshori, 2019; Sunarno \& Prasetyo, 2016). Indikator kemampuan berargumentasi seperti ditunjukkan pada Tabel 2.

Tabel 2. Indikator kemampuan berargumentasi

\begin{tabular}{|l|l|l|}
\hline No. & \multicolumn{1}{|c|}{$\begin{array}{c}\text { Keterampilan } \\
\text { Argumentasi }\end{array}$} & \multicolumn{1}{|c|}{ Indikator Keterampilan Argumentasi } \\
\hline 1 & Klaim & Memilih klaim tentang permasalahan \\
\hline 2 & Data & Menganalisis data untuk mendukung klaim \\
\hline 3 & Bukti & Menjelaskan hubungan antara data dengan klaim \\
\hline 4 & Dukungan & $\begin{array}{l}\text { Membuat dukungan untuk melandasi kebenaran } \\
\text { untuk mendukung klaim berdasarkan teori-teori }\end{array}$ \\
\hline
\end{tabular}


Febi Dwi Putri : Pengembangan Instrumen Tes Kemampuan Berargumentasi pada Materi Impuls dan Momentum

Pedoman penilaian tes kemampuan berargumentasi berdasarkan aspek instrumen tes model TAP dan indikator kemampuan berargumentasi berdasarkan Tabel 3 dibawah ini.

Tabel 3. Pedoman penilaian tes kemampuan berargumentasi

\begin{tabular}{|c|c|c|c|c|c|}
\hline \multirow[t]{2}{*}{ No. } & \multicolumn{2}{|c|}{$\begin{array}{l}\text { Kemampuan } \\
\text { Bergumentasi }\end{array}$} & \multicolumn{3}{|c|}{ Kriteria dan Skor } \\
\hline & Aspek & Penilaian & 1 & 2 & 3 \\
\hline 1 & Klaim & $\begin{array}{l}\text { Ketepatan } \\
\text { klaim }\end{array}$ & $\begin{array}{l}\text { Klaim tidak } \\
\text { akurat }\end{array}$ & $\begin{array}{l}\text { Klaim } \\
\text { sebagian } \\
\text { akurat }\end{array}$ & $\begin{array}{l}\text { Klaim } \\
\text { seluruhnya } \\
\text { akurat }\end{array}$ \\
\hline 2 & Data & $\begin{array}{l}\text { Kecukupan } \\
\text { data }\end{array}$ & $\begin{array}{l}\text { Data tidak } \\
\text { mendukung } \\
\text { klaim }\end{array}$ & $\begin{array}{l}\text { Data tidak } \\
\text { cukup } \\
\text { mendukung } \\
\text { klaim }\end{array}$ & $\begin{array}{l}\text { Data } \\
\text { seluruhnya } \\
\text { mendukung } \\
\text { klaim }\end{array}$ \\
\hline & & $\begin{array}{l}\text { Kualitas } \\
\text { data }\end{array}$ & $\begin{array}{l}\text { Data tidak } \\
\text { dianalisis }\end{array}$ & $\begin{array}{l}\text { Sebagian data } \\
\text { dianalisis }\end{array}$ & $\begin{array}{l}\text { Seluruh data } \\
\text { dianalisis }\end{array}$ \\
\hline 3 & Bukti & $\begin{array}{l}\text { Kualitas } \\
\text { bukti }\end{array}$ & $\begin{array}{l}\text { Bukti yang } \\
\text { disertakan } \\
\text { tidak } \\
\text { mendukung } \\
\text { klaim }\end{array}$ & $\begin{array}{l}\text { Bukti yang } \\
\text { disertakan } \\
\text { sebagian } \\
\text { mendukung } \\
\text { klaim }\end{array}$ & $\begin{array}{l}\text { Bukti yang } \\
\text { disertakan } \\
\text { seluruhnya } \\
\text { mendukung } \\
\text { klaim }\end{array}$ \\
\hline 4 & Dukungan & $\begin{array}{l}\text { Kualitas } \\
\text { dukungan }\end{array}$ & $\begin{array}{l}\text { Dukungan } \\
\text { mendasari } \\
\text { bukti tidak } \\
\text { mendukung } \\
\text { klaim }\end{array}$ & $\begin{array}{l}\text { Dukungan } \\
\text { mendasari } \\
\text { bukti } \\
\text { sebagian } \\
\text { mendukung } \\
\text { klaim }\end{array}$ & $\begin{array}{l}\text { Dukungan } \\
\text { mendasari } \\
\text { bukti } \\
\text { seluruhnya } \\
\text { mendukung } \\
\text { klaim }\end{array}$ \\
\hline
\end{tabular}

(Sumber: Budiyono, 2016)

\section{Tahap Develop}

Setelah menentukan indikator tes kemampuan berargumentasi, maka dilakukan pengembangan instrumen tes. Instrumen tes berupa lima butir soal uraian impuls dan momentum. Soal uraian tes tersebut kemudian dilakukan uji validasi ahli dan uji validasi empirik untuk mengetahui kualitas butir soal. 
Uji validasi ahli dilakukan oleh dua dosen jurusan Fisika FMIPA Universitas Negeri Malang. Dua validator memberikan penilaian terhadap empat aspek, yaitu (1) kesesuaian butir soal dengan indikator butir soal, (2) kesesuaian soal dengan indikator kemampuan berargumentasi, (3) kebenaran soal, dan (4) ketepatan jawaban. Penilaian terdiri dari skala 1 sampai 4 tiap butir aspek. Hasil dari validasi ahli diperoleh bahwa keseluruhan butir soal memperoleh kriteria cukup sehingga layak untuk dikembangkan. Hasil penilaian dari validasi ahli disajikan pada Tabel 4 .

Tabel 4. Hasil Validasi Ahli

\begin{tabular}{|c|c|c|c|c|c|c|c|c|c|c|c|}
\hline \multirow{3}{*}{$\begin{array}{c}\text { Nomor } \\
\text { Soal }\end{array}$} & \multicolumn{8}{|c|}{ Aspek yang Dinilai } & \multirow{3}{*}{$\begin{array}{l}\text { Total } \\
\text { Skor }\end{array}$} & \multirow{3}{*}{$\begin{array}{c}\text { Rata- } \\
\text { rata }\end{array}$} & \multirow{3}{*}{ Kriteria } \\
\hline & \multicolumn{2}{|c|}{$\begin{array}{c}\text { Kesesuaian } \\
\text { butir soal } \\
\text { dengan } \\
\text { indikator } \\
\text { butir soal }\end{array}$} & \multicolumn{2}{|c|}{$\begin{array}{c}\text { Kesesuaian } \\
\text { soal dengan } \\
\text { indikator } \\
\text { kemampuan } \\
\text { argumentasi }\end{array}$} & \multicolumn{2}{|c|}{$\begin{array}{c}\text { Kebenaran } \\
\text { soal }\end{array}$} & \multicolumn{2}{|c|}{$\begin{array}{c}\text { Ketepatan } \\
\text { jawaban }\end{array}$} & & & \\
\hline & V1 & $\mathbf{V 2}$ & V1 & V2 & V1 & $\mathbf{V 2}$ & V1 & $\mathbf{V 2}$ & & & \\
\hline 1 & 4 & 4 & 4 & 3 & 4 & 3 & 3 & 2 & 27 & 13.5 & Cukup \\
\hline 2 & 4 & 4 & 3 & 3 & 2 & 3 & 3 & 3 & 25 & 12.5 & Cukup \\
\hline 3 & 4 & 4 & 3 & 3 & 3 & 3 & 2 & 3 & 25 & 12.5 & Cukup \\
\hline 4 & 4 & 4 & 3 & 4 & 3 & 4 & 3 & 4 & 29 & 14.5 & Baik \\
\hline 5 & 4 & 4 & 4 & 4 & 3 & 4 & 3 & 4 & 30 & 15 & Baik \\
\hline & & & & eselur & uhan & & & & & 13.6 & Cukup \\
\hline
\end{tabular}

Selain data tersebut, juga diperoleh saran dari validator untuk memperbaiki instrumen tes. Saran oleh validator bahwa nomor butir soal 1 perlu diperbaiki dalam pemilihan kata dan nomor butir soal 2 dan 4 perlu diperjelas permasalahan yang ada di soal. Salah satu contoh hasil perbaikan disajikan pada Tabel 5.

Tabel 5. Contoh hasil perbaikan

\begin{tabular}{|c|c|c|}
\hline $\begin{array}{c}\text { Nomor } \\
\text { butir soal }\end{array}$ & \multicolumn{1}{|c|}{ Sebelum } & \multicolumn{2}{|c|}{ Setelah } \\
\hline $\mathbf{1}$ & $\begin{array}{l}\text { Sebuah bola dengan massa m } \\
\text { dan kecepatan v menumbuk } \\
\text { dinding pada sudut 300 dan }\end{array}$ & $\begin{array}{l}\text { Bola dengan massa m dan } \\
\text { kecepatan v menumbuk dinding } \\
\text { membentuk sudut 300 dan }\end{array}$ \\
\hline
\end{tabular}




\begin{tabular}{|l|l|l|}
\hline terpantul dengan kealajuan & terpantul dengan kelajuan yang \\
yang sama pada sudut 300. & sama pada sudut 300. Apakah \\
Apakah terdapat impuls yang & didning memberi impuls pada \\
dikerjakan dinding pada bola? & bola? Jika memberi, berapa \\
Jika ada berapa besar & besar impulsnya? \\
impulnya? & Klaim 1: Dinding memberi \\
Klaim 1: Terdapat impuls yang & impuls pada bola. \\
diekrjakan dinding pada bola. & Klaim 2: Dinding tidak \\
Klaim 2: Tidak ada impuls \\
yang dikerjakan dindidng pada \\
bola.
\end{tabular}

Instrumen tes kemampuan berargumentasi yang dinyatakan layak dapat diuji cobakan pada responden yang dipilih secara acak. Responden terdiri dari 25 mahasiswa semester lima Pendidikan Fisika Universitas Negeri Malang. Berikut ini disajikan Gambar 1 yang merupakan salah satu butir soal dan Gambar 2 merupakan jawaban dari salah satu mahasiswa.

\section{Soal Nomor 1

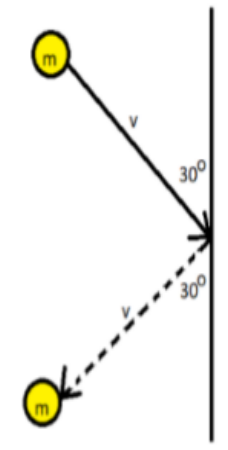 \\ Bola dengan massa $\mathrm{m}$ dan kecepatan $\mathrm{v}$ menumbuk dinding membentuk sudut $30^{\circ}$ dan terpantul dengan kelajuan yang sama pada sudut $30^{\circ}$. Apakah dinding memberi impuls pada bola? Jika memberi, berapa besar impulsnya? \\ Klaim 1: Dinding memberi impuls pada bola \\ Klaim 2: Dinding tidak memberi impuls pada bola}

Gambar 1. Salah satu butir soal tes 
Tuliskan kembali klaim yang dianggap paling tepat!

Klaim:

- Dinding memberí impuls pada bola

Tuliskan data dan analisis data-data untuk mendukung klaim!

\section{Data:}

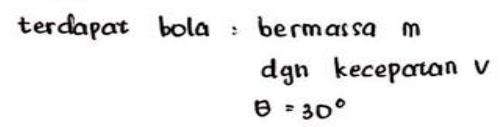

Jelaskan hubungan data yang dituliskan dengan klaim suatu pembenaran!

\section{Bukti:}

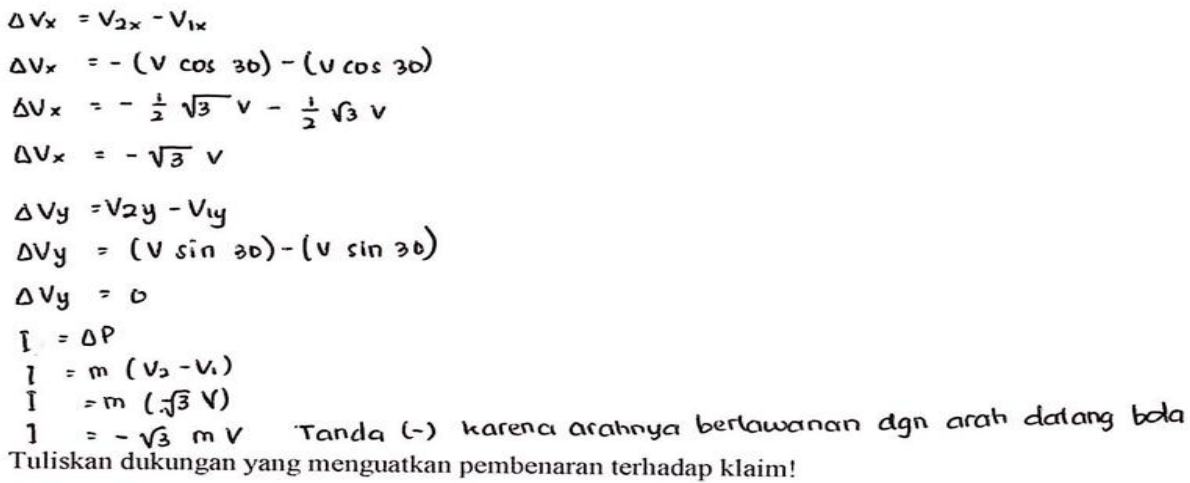

Gambar 2. Jawaban dari salah satu mahasiswa

Berdasarkan hasil dan perolehan skor oleh responden, maka dapat diketahui validasi empirik yang meliputi validitas dan reliabilitas. Tingkat validitas diperoleh dari uji validitas berdasarkan uji korelasi product moment pearson, sedangkan tingkat reliabilitas diperoleh dari hasil uji cronbach alpha.

Uji validitas tiap butir soal dapat dikatakan valid atau tidak berdasarkan perbandingan antara koefisien korelasi pearson ( $\mathrm{r}_{\text {hitung }}$ ) terhadap nilai momen pearson tabel ( $\left.\mathrm{r}_{\text {tabel }}\right)$. Butir soal dikatakan valid jika nilai $\mathrm{r}_{\text {hitung }}$ lebih besar sama dengan $\mathrm{r}_{\text {tabel. }}$. Dengan jumlah responden sebanyak 25 mahasiswa dan taraf signifikansi sebesar 5\%, sehingga besar $r_{\text {tabel }}$ yaitu 0.396. Berikut Tabel 6 merupakan sajian dari hasil uji validitas butir soal. 
Tabel 6. Hasil uji validitas butir soal

\begin{tabular}{|c|c|c|}
\hline $\begin{array}{c}\text { Nomor } \\
\text { Butir Soal }\end{array}$ & $\begin{array}{c}\text { Koefisien Korelasi } \\
\text { Pearson (rhitung) }\end{array}$ & Kriteria \\
\hline 1 & 0.68291 & Valid \\
\hline 2 & 0.63713 & Valid \\
\hline 3 & 0.7082 & Valid \\
\hline 4 & 0.7529 & Valid \\
\hline 5 & 0.4457 & Valid \\
\hline
\end{tabular}

Berdasarkan Tabel 3 diketahui bahwa keseluruhan butir soal dinyatakan valid. Sehingga soal dapat diuji reliabilitas menggunakan uji cronbach alfa dan memperoleh hasil koefisien reliabilitas sebesar 0.78 dengan kriteria reliabel tinggi.

Penggunaan instrumen tes ini diharapkan dapat digunakan untuk mengukur kemampuan berargumentasi mahasiswa. Seperti halnya simulasi (Pallant \& Lee, 2015) dan pemrograman perangkat lunak argumentasi (Shirley Simon, 2008) yang dikembangkan dapat mengukur kemampuan berargumentasi. Instrumen yang dikembangkan berupa tes tertulis agar mahasiswa dapat lebih meningkatkan pemahaman konsep, pencapian literasi sains, dan berpikir kritis terhadap materi impuls dan momentum. Hal ini juga berdasarkan bahwa kemampuan berargumentasi mahasiswa dapat dijaring melalui tes tertulis yang disusun berdasarkan instrumen tes TAP (Soekisno, 2015). Hasil dari pengukuran kemampuan berargumentasi menggunakan instrumen tes ini dapat dideskripsikan dengan mengelompokkan tingkat kemampuan berargumentasi sesuai dengan (Faiqoh dkk., 2018) dimana persentase nilai akhir kemampuan berargumentasi dihitung dengan membandingkan jumlah skor yang diperoleh dengan skor total. Kriteria interpretasi skornya dimulai dari 0\%-19.9\% (sangat buruk), 20\%-39.9\% (kurang baik), 40\%-59.9\% (cukup), 60\%-79.9\% (baik), dan $80 \%-100 \%$ (sangat baik).

\section{SIMPULAN}

Penelitian ini dilakukan untuk mengembangkan instrumen tes kemampuan berargumentasi pada materi impuls dan momentum. Instrumen tes merujuk pada indikator kemampuan berargumentasi sesuai dengan model 
Toulmin's Argument Pattern (TAP). Berdasarkan hasil dari analisis data diperoleh bahwa instrumen tes dengan jumlah lima butir soal uraian dinyatakan layak untuk dikembangkan. Lima butir soal tes dinyatakan valid dan tergolong tingkat reliabel tinggi. Dengan hasil tersebut instrumen tes yang dikembangkan dapat digunakan untuk mengukur kemampuan berargumentasi pada materi impuls dan momentum.

\section{DAFTAR PUSTAKA}

Abduh, N. K., Sastromiharjo, A., \& Anshori, D. S. 2019. Pola Argumentasi pada Genre Teks Eksposisi Karangan Siswa SMA. RETORIKA: Jurnal Bahasa, Sastra, dan Pengajarannya, 12(1), 71.

Budiyono, A. 2016. Pengaruh Penerapan Model Pembelajaran Argument Based Science Inquiry (ABSI) Terhadap Peningkatan Kemampuan Berargumentasi Siswa SMA. Wacana Didaktika, 4(1), 84-93. https://doi.org/10.31102/wacanadidaktika.4.1.84-93.

Cáceres, M., Nussbaum, M., Marroquín, M., Gleisner, S., \& Marquínez, J. T. 2018. Building Arguments: Key to Collaborative Scaffolding. Interactive Learning Environments, 26(3), 355-371.

https://doi.org/10.1080/10494820.2017.1333010.

Dwiretno, G., \& Setyarsih, W. 2018. Pembelajaran Fisika Menggunakan Model Argument Driven Inquiry (Adi) Untuk Melatihkan Kemampuan Argumentasi Ilmiah Peserta Didik. 07(02), 4.

Faiqoh, N., Khasanah, N., Astuti, L. P., Prayitno, R., \& Prayitno, B. A. 2018. Profil Keterampilan Argumentasi Siswa Kelas X dan XI MIPA di SMA Batik 1 Surakarta pada Materi Keanekaragaman Hayati. Jurnal Pendidikan Biologi, 7(3), 174. https://doi.org/10.24114/jpb.v7i3.10122.

Ginanjar, W. S., Utari, S., \& Muslim, Dr. 2015. Penerapan Model ArgumentDriven Inquiry Dalam Pembelajaran Ipa Untuk Meningkatkan Kemampuan Argumentasi Ilmiah Siswa SMP. Jurnal Pengajaran Matematika dan Ilmu Pengetahuan Alam, 20(1), 32.

Handayani, P. 2015. Analisis Argumentasi Peserta Didik Kelas X SMA Muhammadiyah 1 Palembang dengan Menggunakan Model Argumentasi Toulmin. 2(1), 9. https://doi.org/10.36706/jipf.v2i1.2355. 
Febi Dwi Putri : Pengembangan Instrumen Tes Kemampuan Berargumentasi pada Materi Impuls dan Momentum

Herring, J. 2012. How to Argue: Powerfully, Persuasively, Positively. Upper Saddle River, N.J: FT Press.

Jennings, P. A., \& Greenberg, M. T. 2009. The Prosocial Classroom: Teacher Social and Emotional Competence in Relation to Student and Classroom Outcomes. Review of Educational Research, 79(1), 491-525. https://doi.org/10.3102\%2F0034654308325693.

Kaniawati, I., \& Suhandi, A. 2014. Penerapan Model Pembelajaran Pembangkit Argumen Menggunakan Metode Saintifik Untuk Meningkatkan Kemampuan Kognitif Dan Keterampilan Berargumentasi Siswa. Jurnal Pendidikan Fisika Indonesia, 10(2), 104-116. https://doi.org/10.15294/jpfi.v10i2.3347.

Karim, S., Saepuzaman, D., \& Sriyansyah, S. P. 2015. Diagnosis Kesulitan Belajar Mahasiswa Dalam Memahami Konsep Momentum. Jurnal Penelitian \& Pengembangan Pendidikan Fisika, 01(1), 85-90.

Kontos, P., Miller, K.-L., Mitchell, G. J., \& Stirling-Twist, J. 2017. Presence redefined: The Reciprocal Nature of Engagement Between Elder-Clowns and Persons with Dementia. Dementia, 16(1), 46-66. https://doi.org/10.1177\%2F1471301215580895.

Kurniawan, B. R., \& Taqwa, M. R. A. 2018. Pengembangan Instrumen Tes Kemampuan Pemecahan Masalah Fisika pada Materi Listrik Dinamis. Jurnal Pendidikan: Teori, Penelitian, dan Pengembangan, 3(11), 14511457. http://dx.doi.org/10.17977/jptpp.v3i11.11761.

Noroozi, O., Hatami, J., Bayat, A., van Ginkel, S., Biemans, H. J. A., \& Mulder, M. 2018. Students' Online Argumentative Peer Feedback, Essay Writing, and Content Learning: Does Gender Matter? Interactive Learning Environments, 1-15. https://doi.org/10.1080/10494820.2018.1543200.

Paglieri, F., \& Castelfranchi, C. 2010. Why Argue? Towards A Cost-Benefit Analysis of Argumentation. Argument \& Computation, 1(1), 71-91. https://doi.org/10.1080/19462160903494584.

Pallant, A., \& Lee, H.-S. 2015. Constructing Scientific Arguments Using Evidence from Dynamic Computational Climate Models. Journal of Science Education and Technology, 24(2-3), 378-395. https://doi.org/10.1007/s10956-014-9499-3.

Probosari, R. M., Ramli, M., \& Sajidan, Mr. 2015. Dampak Pembelajaran Inkuiri Berjenjang dalam Meningkatkan Keterampilan Menulis Argumentatif 
Calon Guru. Jurnal Pengajaran Matematika dan Ilmu Pengetahuan Alam, 6(1), 155.

Rahmawati, I. L., Hartono, H., \& Nugroho, S. E. 2015. Pengembangan Asesmen Formatif Untuk Meningkatkan Kemampuan Self Regulation Siswa Pada Tema Suhu Dan Perubahannya. Unnes Science Education Journal, 4(2). Ramdani, Y. 2012. Pengembangan Instrumen dan Bahan Ajar untuk Meningkatkan Kemampuan Komunikasi, Penalaran, dan Koneksi Matematis dalam Konsep Integral. Jurnal Penelitian Pendidikan, 13(1), 44-52.

Rhahim, E., Tandililing, E., \& Mursyid, S. 2015. Hubungan Keterampilan Matematika Dengan Kemampuan Menyelesaikan Soal Fisika Terhadap Miskonsepsi Siswa pada Impuls Momentum. Jurnal Pendidikan dan Pembelajaran Khatulistiwa, 4(9).

Rosa, G. C., Cari, C., \& Aminah, N. S. 2017. Tingkat Pemahaman Konsep Mahasiswa Pendidikan Fisika Universitas Sebelas Maret pada Materi Momentum. Prosiding SNFA (Seminar Nasional Fisika dan Aplikasinya), 2, 74.

Rosita, C. D. 2014. Kemampuan Penalaran Dan Komunikasi Matematis: Apa, Mengapa, dan Bagaimana Ditingkatkan Pada Mahasiswa. Euclid, 1(1), 14.

Simon, Shirley. 2008. Using Toulmin's Argument Pattern in the Evaluation of Argumentation in School Science. International Journal of Research \& Method in Education 31 (3): 277-89. https://doi.org/10.1080/17437270802417176.

Soekisno, R. B. A. 2015. Pembelajaran Berbasis Masalah Untuk Meningkatkan Kemampuan Argumentasi Matematis Mahasiswa. Infinity Journal, 4(2), 120. https://doi.org/10.22460/infinity.v4i2.p120-139

Sudarmo, N. A., Lesmono, A. D., \& Harijanto, A. 2018. Analisis Kemampuan Berargumentasi Ilmiah Siswa SMA pada Konsep Termodinamika. Jurnal Pembelajaran Fisika, 7(2), 196-201.

Suhandi, A. 2012. Pengembangan Perangkat Pembelajaran Fisika Sekolah Untuk Meningkatkan Pemahaman Konsep dan Kemampuan Berargumentasi Calon Guru Fisika. Jurnal pendidikan fisika Indonesia, 8(2). https://doi.org/10.15294/jpfi.v8i2.2157. 
Febi Dwi Putri : Pengembangan Instrumen Tes Kemampuan Berargumentasi pada Materi Impuls dan Momentum

Viyanti, V., Cari, C., Sunarno, W., \& Prasetyo, Z. K. 2016. Analisis tes argumentasi materi terapung dan tenggelam. Jurnal Pendidikan Fisika dan Keilmuan (JPFK), 2(2), 88-91.

Thiagarajan, S, Semmel dan Semmel. 1974. Instructional Development for Training Teacher of Exceptional Children. Minnesota: Indiana University.

Yusup, F. 2018. Uji Validitas dan Reliabilitas Instrumen Penelitian Kuantitatif. Jurnal Tarbiyah: Jurnal Ilmiah Kependidikan, 7(1). 